\title{
Physicochemical properties and oxidative stabilities of chicken breast jerky treated various sweetening agents
}

\author{
Dong-Geon Nam, Beom-Gyun Jeong, Jiyeon Chun* \\ Department of Food Science and Technology, Sunchon National University, Suncheon 57922, Korea
}

\section{당침지 처리된 닭 가슴살 육포의 이화학적 특성 및 산화안정성}

\author{
남동건 · 정범균 · 천지연* \\ 순천대학교 식품과학부 식품공학전공
}

\begin{abstract}
Chicken breast jerky (CJ) was prepared by drying chicken breast at $50^{\circ} \mathrm{C}$ for 9 hrs after marinating it in a various sweetening sauce including white sugar (WS), brown sugar (BS), rice synup (RS), fructooligosaccharide (FO), pineapple concentrate (PC), Rubus coreanus extract (RCE), or honey (H), and its physicochemical and sensory properties were investigated. The $\mathrm{CJ}$ was found to contain $22.5-25.0 \%$ moisture, $41.0-46.6 \%$ protein, and $0.4-1.0 \%$ fat, which indicates that it could serve as a high-protein and low-fat snack. The type of sweeteners significantly affected the yield, $\mathrm{pH}$, total viable cell count, and water activity of the $\mathrm{CJ}$, showing ranges of 40.9-50.1\%, 5.2-5.9, 2.5-6.2 $\times 10^{4}$ $\mathrm{CFU} / \mathrm{g}$, and 0.74-0.81, respectively. Both the water activity and $\mathrm{pH}$ were the lowest in CJ-RCE where of the highest in CJ-WS. The cohesiveness, springiness, and chewiness of the CJ significantly differed depending on the type of sweeteners $(\mathbf{p}<\mathbf{0 . 0 5})$. CJ-RCE showed the best taste and overall acceptability in a sensory test. After storage at $50^{\circ} \mathrm{C}$ for 2 weeks, thiobarbituric acid reactive substance (TBARS) content $(58.3$ malondialdehyde (MDA) $\mathrm{mg} / \mathrm{kg}$ ) of CJ-RCE was much lower than those of control beef $(75.6 \mathrm{MDA} \mathrm{mg} / \mathrm{kg})$ and pork jerky $(98.0 \mathrm{MDA} \mathrm{mg} / \mathrm{kg})$, showing the good oxidative stability of CJ-RCE. Overall, marination in RCE sauce was suitable for the preparation of $\mathrm{CJ}$ with good quality in terms of its water activity, fat and protein contents, sensory property and oxidative stability.
\end{abstract}

Key words : chicken breast jerky, water activity, sensory property, oxidative stability

\section{서 론}

닭고기는 우육과 돈육에 비하여 가격이 저렴하고 지방함 량이 상대적으로 낮아 저지방 고단백 건강 식이를 추구하는 현대인들의 요구에 잘 부응하고 있다. 이는 웰빙 (well-being) 식이 경향과 함께 꾸준히 소비량이 늘어날 것 으로 전망된다(1). 닭은 통째로 또는 부분 육으로 분할 가공 되어 이용되고 있는데 이 중에서 특히 닭 가슴살은 지방이

*Corresponding author. E-mail : cjyfall@sunchon.ac.kr Phone : 82-61-750-3258, Fax : 82-61-750-3208

Received 19 January 2017; Revised 1 February 2017; Accepted 2 February 2017.

Copyright (c) The Korean Society of Food Preservation. All rights reserved.
약 $0.4 \mathrm{~g} / 100 \mathrm{~g}$ 인데 반하여 단백질 함량은 약 $23.3 \mathrm{~g} / 100$ $\mathrm{g}$ 수준으로 다른 부위에 비하여 저지방 및 고단백질 재료로 최근 다이어트나 근육 운동을 하는 사람들로부터 선호되는 부위이다(2). 그러나 일반 조리법으로 제조된 닭 가슴살은 퍽퍽한 조직감으로 인하여 한정적으로 이용되고 있어 다양 한 가공을 통하여 손쉽고 다양하게 이용할 수 있는 제품 개발이 요구되고 있다.

육포는 절임이나 건조에 의해 수분활성도를 줄임으로써 미생물의 성장을 억제시키는 가장 오래된 건조, 저장 식품 중 하나이다(3). 육포 제조 시 사용되는 염류나 당류 등의 첨가는 보습력을 높이면서도 미생물이 이용 가능한 수분함 량을 낮추게 되므로 조직감은 개선되면서도 수분활성도를 효과적으로 저하시키는 방법으로 저장성과 품질 향상에 널리 이용되고 있다(4-5). 일반적으로 육포는 우육으로 제 
조된 우 육포(beef jerky)가 널리 이용되고 있으나 최근 소비 자들의 다양해진 기호성으로 인하여 돈육 또는 가금육을 이용한 육포 개발이 시도되고 있다.

적색육(red meat)인 우육이나 돈육을 이용한 육포에 관한 연구는 당류와 염류 첨가(6-10), 부재료 첨가(11-15), 건조 방법(16-21), 저장 중 미생물에 의한 변패 억제(1,22-26) 등 이 보고되어 있다. 이에 반하여 백색육(white meat)으로 구 분되는 가금육은 우육이나 돈육에 비하여 조직이 부드럽고 관능적 특성에 차이를 나타내어 우 육포과 돈 육포와는 다른 제조 특성을 나타낼 것으로 보이나 이에 관한 연구로 연육제 처리 닭고기 육포의 이화학적 특성(26), 칠면조 육포 의 품질 특성(27) 등에 관한 연구 외에는 거의 전무한 실정 으로 가금육 육포 산업화를 위한 기초 연구 자료 구축이 요구되고 있다.

본 연구에서는 닭 가슴살을 원료로 선택하여 다양한 감 미제를 사용한 침지용액을 처리하여 닭 가슴살 육포를 제조 하고 이들의 이화학적 및 관능적 품질 특성을 조사하였다. 또한 관능적으로 우수한 닭 가슴살 육포를 선정하여 동일한 방법으로 제조한 돈 육포와 우 육포와의 산화 안정성을 비교하였다.

\section{재료 및 방법}

\section{재 료}

닭 가슴살은 주식회사 올품(경상북도 상주시 발산로 135)의 가공 포장된 냉동 닭가슴살 부위를 구매하여 사용하 였다. 닭 가슴살 침지용액에 사용된 양조간장(Sampio, Seoul, Korea), 백설탕(TS Corporation, Seoul, Korea), 황설 탕(TS Corporation, Seoul, Korea), 조청(Daesang, Seoul, Korea), 프락토올리고당(CJ Cheiljedang, Seoul, Korea), 파 인애플 농축액(Chungsol-Food, Boeun, Korea), 복분자 엑기 스(Bohae B\&F, Jangseong, Korea), 잡화꿀(Kkohshaem Food, Pocheon, Korea), 미림(Lotte Chilsung Beverage, Seoul, Korea), 후춧가루(Ottogi, Anyang, Korea), 마늘가루 (Samyang Foods, Seoul, Korea), 바질(International Spice \& Food Import, Braine-I'Alleud, Belgium) 등을 시중 마켓에서 구입하여 사용하였다. 시료의 이화학적 특성 및 산화안정 성 품질 특성 분석에 사용한 시약은 1 급 및 특급시약을 사용하였다.

\section{육포의 제조}

닭 가슴살은 육포의 씹는 조직감을 부여하기 위해 조직 의 결 방향으로 $0.5 \mathrm{~cm}$ 너비로 $(1 \mathrm{~cm}$ 두께 $)$ 슬라이스하였으 며 백설탕(white sugar), 황설탕(brown sugar), 조청(rice syrup), 프락토올리고당(fructo-oligosaccharide), 파인애플 농축액(pineapple concentrate), 복분자 엑기스(Rubus coreanus extract), 꿀(honey)을 감미제로 사용한 7종의 침지용액에 각각 실온에서 30 분간 침지 후 건져낸 다음 $50^{\circ} \mathrm{C}$ drying oven(HB-501S, Hanbaek Sci, Bucheon, Korea)에서 9시간 동안 건조하였다. 건조된 육포는 실온에서 약 40 분간 냉각 시킨 후 데시케이터에 보관하며 분석에 사용하였다. 육포 제조를 위한 침지용액의 배합비는 Table 1 과 같다.

\section{일반성분 분석}

제조된 닭 가슴살 육포의 일반성분 분석은 $\mathrm{AOAC}$ 방법으 로 측정하였다(28). 조수분 함량은 잘게 분쇄된 닭 가슴살 육포 시료를(약 $5 \mathrm{~g})$ 알루미늄 접시에 칭량하고 $105^{\circ} \mathrm{C}$ 에서 22 시간 동안 건조시킨 다음 데시케이터에서 30 분간 방냉 후 무게변화를 측정하여 수분함량을 계산하였다. 조단백은 Kjeldahl법으로 Kjeldahl 장치(Auto Kjeldahl Unit K-370, BUCHI, Flawil, Switzerland)에서 측정된 질소량에 질소계 수 6.25 를 곱하여 산출하였으며, 조지방은 Soxhlet법으로 Soxhlet 장치(Soxtec ${ }^{\mathrm{TM}} 2050$ auto fat extraction system, FOSS, Hilleroed, Denmark)을 사용하여 정량분석하였다.

Table 1. Ingredients of seasoning solutions used for manufacturing chicken breast jerky

\begin{tabular}{cc}
\hline Ingredients & Unit amount \\
\hline Sweetener (WS, BS, RS, FO, PC, RCE, or H) & $29.3 \mathrm{~g}$ \\
Mirim & $5.9 \mathrm{~mL}$ \\
Black pepper powder & $1.0 \mathrm{~g}$ \\
Garlic powder & $4.9 \mathrm{~g}$ \\
Dried basil leave & $0.5 \mathrm{~g}$ \\
Water & $14.6 \mathrm{~mL}$ \\
Soy sauce & $43.9 \mathrm{~mL}$ \\
\hline
\end{tabular}

${ }^{1)} \mathrm{WS}$, white sugar; BS, brown sugar; RS, rice syrup; FO, fructo-oligosaccharide; PC, pineapple concentrate; RCE, Rubus coreanus extract; $\mathrm{H}$, honey.

\section{$\mathrm{pH}$ 측정}

분쇄된 닭 가슴살 육포 약 $1 \mathrm{~g}$ 을 취하여 증류수 $10 \mathrm{~mL}$ 을 가한 후 15 분간 방치한 다음 homogenizer(IKA ${ }^{\circledR} \mathrm{T} 10 \mathrm{basic}$, ULTRA-TURRAX, Staufen, Germany)로 5분간 균질화시킨 후 시료액의 $\mathrm{pH}$ 를 $\mathrm{pH}$ meter(Mettler-Toledo $\mathrm{AG}$ 8603, Schwerzenbach, Switzerland)로 측정하였다.

\section{제조수율}

침지용액에 침지 후 건조된 닭 가슴살 육포와 육포 제조 에 사용된 닭 가슴살의 무게를 측정하여 아래와 같이 육포 제조수율을 계산하였다.

$$
\text { 수율 }(\%)=\frac{\text { 건조된 닭 가슴살 육포의 무게 }(\mathrm{g})}{\text { 건조 전 닭 가슴살의 무게 }(\mathrm{g})} \times 100
$$




\section{총균수 측정}

분쇄된 닭 가슴살 육포 시료 약 $1 \mathrm{~g}$ 에 멸균수 $10 \mathrm{~mL}$ 을 가한 후 homogenizer로 1 분간 균질화한 다음 멸균수를 이용 하여 단계 희석한 후 plate count agar(PCA, Becton, Dickinson and Company, Difco ${ }^{\mathrm{TM}}$, Sparks, MD, USA)배지를 사용하여 $37^{\circ} \mathrm{C}$ 의 온도로 48 시간 배양 후 생성된 colony수를 계수하였다.

\section{수분활성도 및 색도 측정}

건조된 닭 가슴살 육포 시료를 믹서기(Blender HGBSSSS6, WARING, Torrington, CT, USA)로 분쇄한 시료를 측정 용 기에 약 $5 \mathrm{~g}$ 칭량 후 수분활성도 측정기(AQS-2, Nagy mess system, Gaeufelden, Germamy)의 온도를 $25^{\circ} \mathrm{C}$ 로 평형 수분 함량에 도달시킨 다음 수분활성도를 측정하였다. 시료의 색도는 분쇄된 육포를 색차계(CR-200, Minolta, Tokyo, $\mathrm{Japan}$ )를 사용하여 명도(L, lightness), 적색도(a, redness), 황색도(b, yellowness), $\Delta \mathrm{E}$ (color difference)를 측정하였다. 색차계는 측정 전 표준백판을 이용하여 보정 $(\mathrm{L}=97.06$, $\mathrm{a}=-0.15, \mathrm{~b}=+1.94)$ 하여 사용하였다.

\section{조직감 측정}

건조된 닭 가슴살 육포의 물성은 texture analyzer (CT3-10K, BROOKFIELD, Middleboro, MA, USA)에 실린 더 모양의 probe(TA10, $12.7 \mathrm{~mm}$ clear cylinder probe)를 장착 하여 제조된 육포 조직의 방향과 수직으로 누르면서 경도 (hardness), 응집성(cohesiveness), 탄력성(springiness), 검성 (gumminess), 씹힘성(chewiness)을 분석하였다. 분석조건 은 trigger load $20 \mathrm{~g}$, test speed $2 \mathrm{~mm} / \mathrm{s}$, load cell 10,000 $\mathrm{g}$ 으로 설정하여 측정하였고 총 5 회 반복 실험하여 평균과 표준편차를 구하였다.

\section{관능검사}

훈련된 관능검사 패널 15 명을 구성하여 5점 기호척도법 으로 색(color), 향(flavor), 맛(taste), 조직감(texture), 전체적 기호도(overall acceptability)를 평가하였다. 관능검사에 사 용된 닭 가슴살 육포 시료는 $1.5 \times 1.5 \mathrm{~cm}$ 로 균일하게 잘라 난수표 번호를 식별 번호로 표시하여 제공하였다.

\section{닭 가슴살 육포의 저장 중 산화안정성 조사}

이화학적 특성 및 관능평가에서 가장 우수한 품질의 닭 가슴살 육포를 선정하고 플라스틱 밀폐용기에 $5 \mathrm{~g}$ 씩 시료 를 분할 밀봉한 후 $50^{\circ} \mathrm{C}$ 의 incubator(HB-103LP, Hanbaek Sci, Bucheon, Korea)에서 저장하면서 2일 간격으로 시료를 채취하여 thiobarbituric acid reactive substances(TBARS)를 측정하였다. 동일한 방법으로 제조한 우둔살을 이용한 우 육포와 뒷 다리살을 이용한 돈 육포를 산화안정성 비교를 위한 대조구로 사용하여 같은 방법으로 저장하였으며 이들
의 TBARS 측정방법은 다음과 같다. 시료 약 $2 \mathrm{~g}$ 을 칭량 후 $0.2 \%$ butylated hydroxy toluene(BHT) $0.3 \mathrm{~mL}$ 과 $3.86 \%$ perchrolic acid $18 \mathrm{~mL}$ 을 가해 산화반응을 정지시키고 2분간 균질화한 후 여과지(Whatman No. 1)로 여과하였다. 여과액 $1 \mathrm{~mL}$ 에 thiobarbituric $\operatorname{acid}(\mathrm{TBA})$ 용액을 $1 \mathrm{~mL}$ 씩 가하여 5 분간 혼합한 다음 끓는 물에서 35 분간 열처리한 후 냉각시 켰다. 반응액은 $450 \times g$ 에서 20 분간 원심분리 후 상층액을 취하여 $530 \mathrm{~nm}$ 에서 흡광도를 측정하였다. 공시험은 시료 대신 증류수를 가하여 위와 같은 방법으로 처리하였다. 시 료의 TBARS 값은 1,1,3,3-tetraethoxypropane을 표준물질로 사용하여 다음과 같이 malondialdehyde(MDA) $\mathrm{mg} / \mathrm{kg}$ 로 나 타내었다.

TBARS $(\mathrm{MDA} \mathrm{mg} / \mathrm{kg})=(\mathrm{A}-\mathrm{B}) \times$ 희석배수 $\times 100 / \mathrm{S}$
$\mathrm{A}$ : 시료의 $530 \mathrm{~nm}$ 에서의 흡광도
$\mathrm{B}$ : 공시료의 $530 \mathrm{~nm}$ 에서의 흡광도
$\mathrm{S}$ : 시료 채취량 $(\mathrm{g})$

\section{통계처리}

통계분석은 SPSS 프로그램(SPSS 19.0 Windows, SPSS Inc.)을 통해 일원 배치 분산분석(Oneway-ANOVA)을 하였 고 처리구간의 평균간 비교는 Duncan의 다중범위시험법을 통하여 $\mathrm{p}<0.05$ 수준에서 유의성을 검정하였다.

\section{결과 및 고찰}

\section{닭 가슴살 육포의 일반성분}

감미제 종류를 달리한 침지용액을 이용하여 제조한 닭 가슴살 육포의 일반성분 함량은 Table 2 와 같다. 닭 가슴살 육포의 수분은 $22.4-24.5 \%$, 조단백 $40.4-48.6 \%$, 조지방 0.4-0.9\%로 나타나 고단백 저지방의 중간수분함량 제품임 을 확인할 수 있었다. 이들 함량은 감미제의 종류에 따른 유의적으로 차이가 나타났으나 $(\mathrm{p}<0.05)$ 그 차이가 미미한 수준이었다. 한편, Park 등(29)의 연구에서 당을 첨가한 우 육포가 당을 첨가하지 않은 우 육포보다 수분함량이 높게 나타났으며 당첨가군 중에서는 올리고당, 꿀, 설탕을 첨가 한 육포의 순으로 높게 나타났다고 보고하여 육포 제조에 사용되는 당의 종류에 따라서 수분함량에 영향을 미칠 수 있음을 보여주었다. 한국식품개발연구원의 농축산 가공표 준화 KS 연구보고서(30)에 따르면 육포의 표준 규격은 수 분 $25.0 \%$ 이하, 단백질 $40.0 \%$ 이상, 지방 $10.0 \%$ 이하로 본 연구에서 제조된 닭 육포의 경우 이러한 표준규격에 맞는 수준으로 제조된 것으로 보여진다.

일반적으로 시판되는 우 육포 및 돈 육포는 조수분 17.0-21.5\%, 조단백 55.0-65.5\%, 그리고 조지방 7.0-8.5\%의 
범위로 나타내는데 이에 비하여 본 연구에서 제조된 닭 가슴살 육포는 단백질 함량이 다소 낮으나 건조 시간을 길게 하여 수분함량을 우 육포와 같이 $20 \%$ 이하로 낮춘다 면 약 $50 \%$ 수준의 단백질 함량을 가지는 육포를 제조할 수 있을 것으로 보여진다. 한편, 우 육포와 돈 육포의 경우 지방 함량이 약 7-8\%로 높은데 반하여 본 연구에서 닭 가슴 살로 제조한 닭 육포의 경우 약 $1 \%$ 수준의 지방함량을 나타내어 저지방 고단백 제품임을 확인할 수 있었다. 닭 가슴살 원육의 지방 함량은 국외 자료의 경우 $1.20 \%(31)$, 국내 시판 닭 가슴살의 경우 0.2-0.8\%(2)로 알려져 있다. 이는 원료육의 종류 및 부분육의 선정에 따라 저지방 및 고단백 식이를 위한 육포 제조가 가능할 것으로 판단된다. 한편, 연화제를 첨가하여 제조한 닭육포의 이화학적 특성 을 연구한 Yang 등(32)은 노계의 닭가슴살을 이용하여 만든 육포의 조수분 $25.87-27.55 \%$, 조단백 $43.98-48.91 \%$, 조지방 5.94-7.30\%로 보고하였으며 Lee와 $\operatorname{Kim}(33)$ 은 닭 다리살을 이용한 육포의 경우 조수분 $27.36 \%$, 조단백 $39.76 \%$, 조지방 $22.75 \%$ 로 보고하여 원료육에 따라 일반성분 함량에 차이를 나타냄을 보여주었다. 본 연구에서 제조된 닭 육포의 경우 지방 함량이 이보다 낮게 나타났는데 이는 원료육 및 부분 육의 특성 차이 때문인 것으로 생각되며 육포 제조 시 원료 육의 일반성분 특성을 고려한 선택이 필요할 것으로 사료 된다.

Table 2. Proximate compositions of chicken breast jerky prepared using different types of sweeteners

\begin{tabular}{cccc}
\hline \multirow{2}{*}{ Sweeteners $^{1)}$} & \multicolumn{3}{c}{ Contents (\%) } \\
\cline { 2 - 4 } & Moisture & Crude protein & Crude lipid \\
\hline WS & $\left.23.9 \pm 0.9^{\mathrm{ns} 2}\right)$ & $46.6 \pm 2.2^{\mathrm{a} 3)}$ & $0.8 \pm 0.0^{\mathrm{ab}}$ \\
BS & $22.5 \pm 0.7$ & $48.6 \pm 1.9^{\mathrm{a}}$ & $0.7 \pm 0.1^{\mathrm{b}}$ \\
RS & $22.4 \pm 1.2$ & $44.7 \pm 2.9^{\mathrm{ab}}$ & $0.5 \pm 0.1^{\mathrm{c}}$ \\
FO & $23.9 \pm 0.6$ & $40.4 \pm 3.8^{\mathrm{b}}$ & $0.4 \pm 0.2^{\mathrm{c}}$ \\
PC & $23.9 \pm 0.7$ & $41.0 \pm 3.4^{\mathrm{b}}$ & $0.9 \pm 0.1^{\mathrm{a}}$ \\
RCE & $24.0 \pm 0.7$ & $45.0 \pm 0.8^{\mathrm{ab}}$ & $0.7 \pm 0.0^{\mathrm{b}}$ \\
H & $24.5 \pm 0.7$ & $44.9 \pm 1.3^{\mathrm{ab}}$ & $0.8 \pm 0.1^{\mathrm{ab}}$ \\
\hline
\end{tabular}

${ }^{1)}$ WS, white sugar; BS, brown sugar; RS, rice syrup; FO, fructo-oligosaccharide; PC, pineapple concentrate; RCE, Rubus coreanus extract; H, honey.

2) ns, not significant.

${ }^{3)}$ All values are mean \pm SD. Values with different superscript small letters in the same column are significantly different by Duncan's multiple range test at $p<0.05$. $a>b>c$.

\section{닭 가슴살 육포의 $\mathrm{pH}$, 총균수, 제조 수율}

감미제 종류를 달리한 침지용액으로 제조한 닭 가슴살 육포의 $\mathrm{pH}$, 총균수, 제조수율은 Table 3 과 같다. $\mathrm{pH}$ 는 수분 활성도와 같이 식품 저장 시 미생물 생육을 저해할 수 있는 요인으로 식품 가공 및 저장에 이용되는 중요한 지표이다. 닭 가슴살 육포의 $\mathrm{pH}$ 는 감미제의 종류에 따라 유의적인 차이를 나타내었으며 $(\mathrm{p}<0.05)$ 최저 5.20 (복분자 엑기스)에
서 최고 5.91(프락토올리고당)의 범위를 나타냈다. 파인애 플 농축액과 복분자 엑기스 첨가군이 다른 감미제 시료와 비교하여 상대적으로 낮은 $\mathrm{pH}$ 를 보인 것은 과실이 포함하 고 있는 유기산 함량 때문인 것으로 보여진다. 일반적으로 육가공품에 사용되는 염들은 알칼리성으로 대체로 원료육 에 비하여 육가공품의 $\mathrm{pH}$ 가 높아지는 것으로 보고되는데 (34) 육포 형태의 가공품 제조 시 과실 농축액의 사용은 감미의 역할 뿐 아니라 $\mathrm{pH}$ 를 낮추는데 기여함으로 저장성 을 높일 수 있을 것으로 보여진다.

닭 가슴살 육포의 총균수는 감미제의 종류에 따라 $2.5-6.2 \times 10^{4} \mathrm{CFU} / \mathrm{g}$ 의 범위 안에서 유의적인 차이를 보였으 나 모두 $10^{4} \mathrm{CFU} / \mathrm{g}$ 의 수준으로 큰 차이를 나타내지는 않았 다. 시판되는 돈 육포의 경우 $4.3 \times 10^{3} \mathrm{CFU} / \mathrm{g}$, 우 육포는 $6.9 \times 10^{3} \mathrm{CFU} / \mathrm{g}$ 수준으로 보고되어 있으며(25), Jeong 등(35) 은 시판 육포의 경우 $10^{3}-10^{4} \mathrm{CFU} / \mathrm{g}$ 정도의 생균수가 검출 되는 것으로 보고하였다. 최근 식품의약품안전처에서는 가 공육포를 건조저장육류(식품기준 및 규격 정부개정고시 2016-154)로 분류하고, 일반세균수 $10^{5} \mathrm{CFU} / \mathrm{g}$ 이하로 제한 하여 관리하고 있다. 본 연구에서 제조된 닭 가슴살 육포는 모두 $10^{4} \mathrm{CFU} / \mathrm{g}$ 수준으로 나타나 이러한 가공육포 관리기 준을 충족하고 있는 것으로 보여진다.

한편, 닭 가슴살 육포의 제조 수율은 감미제 종류에 따라 유의적인 차이를 나타내었는데 백설탕을 사용한 침지용액 으로 제조한 육포가 $50.1 \%$ 로 가장 높게 나타났으며 다음으 로 복분자 엑기스(47.0\%), 황설탕(46.6\%), 조청(45.7\%), 꿀 (44.2\%), 파인애플 농축액(43.8\%), 프락토올리고당 $(40.9 \%)$ 순으로 나타났다. 일반적으로 건조 공정을 통해 제조되는 육포의 제조 수율은 육포 제조 시 침지용액에 사용되는 부재료 중의 염류, 당류 등 성분들의 수분과의 결합능력의 차이에 영향을 받는 것으로 알려져 있으며 본 연구에서는 백설탕과 복분자 엑기스가 육포 제조 수율이 높게 나타나

Table 3. Yield, viable cell number, water activity, and $\mathrm{pH}$ of chicken breast jerky prepared using different types of sweeteners

\begin{tabular}{ccccc}
\hline Sweeteners ${ }^{1)}$ & $\mathrm{pH}$ & $\begin{array}{c}\text { Total viable cell } \\
(\mathrm{CFU} / \mathrm{g})\end{array}$ & $\begin{array}{c}\text { Yield }^{2} \\
(\%)\end{array}$ & Water activity \\
\hline WS & $5.90 \pm 0.01^{\mathrm{a})}$ & $4.9^{\mathrm{b}} \times 10^{4}$ & $50.1 \pm 0.1^{\mathrm{a}}$ & $0.812 \pm 0.007^{\mathrm{a}}$ \\
BS & $5.83 \pm 0.01^{\mathrm{b}}$ & $3.2^{\mathrm{c}} \times 10^{4}$ & $46.6 \pm 0.2^{\mathrm{b}}$ & $0.772 \pm 0.002^{\mathrm{d}}$ \\
RS & $5.71 \pm 0.01^{\mathrm{c}}$ & $4.7^{\mathrm{b}} \times 10^{4}$ & $45.7 \pm 0.3^{\mathrm{c}}$ & $0.777 \pm 0.006^{\mathrm{cd}}$ \\
FO & $5.91 \pm 0.01^{\mathrm{a}}$ & $62^{\mathrm{a}} \times 10^{4}$ & $40.9 \pm 0.1^{\mathrm{e}}$ & $0.783 \pm 0.003^{\mathrm{c}}$ \\
PC & $5.55 \pm 0.01^{\mathrm{e}}$ & $2.6^{\mathrm{c}} \times 10^{4}$ & $43.8 \pm 0.2^{\mathrm{d}}$ & $0.793 \pm 0.004^{\mathrm{b}}$ \\
RCE & $5.20 \pm 0.01^{\mathrm{f}}$ & $2.8^{\mathrm{c}} \times 10^{4}$ & $47.0 \pm 0.2^{\mathrm{b}}$ & $0.744 \pm 0.005^{\mathrm{f}}$ \\
H & $5.67 \pm 0.01^{\mathrm{d}}$ & $2.5^{\mathrm{c}} \times 10^{4}$ & $44.2 \pm 0.8^{\mathrm{d}}$ & $0.755 \pm 0.006^{\mathrm{e}}$ \\
\hline
\end{tabular}

${ }^{1)} \mathrm{WS}$, white sugar; BS, brown sugar; RS, rice syrup; FO, fructo-oligosaccharide; PC, pineapple concentrate; RCE, Rubus coreanus extract; H, honey.

${ }^{2)}$ Yield $(\%)=($ Weight of chicken brest jerky/Weight of raw chicken breast $) \times 100$.

${ }^{3)}$ All values are mean $\pm S D$. Values with different superscript small letters in the same column are significantly different by Duncan's multiple range test at $\mathrm{p}<0.05$. $a>b>c>d>e>f$. 
닭 가슴살에서의 수분 보유력이 상대적으로 우수한 것으로 보여진다. Song(7)은 글리세롤, 조청, 꿀을 사용하여 우육포 를 제조 시 동일한 건조 조건에서 글리세롤과 설탕을 사용 한 육포의 수율이 높게 나타났다고 보고하여 첨가된 당 종류가 제조 수율에 영향을 미칠 수 있음을 보여주었다. 이러한 결과는 사용된 육원료의 특성 및 사용된 부재료의 종류에 따라 보수성이 달라질 수 있는 것으로 제조 수율에 영향을 미침을 나타낸다. 이 외에도 육포 제조 시 건조 수율 에 영향을 주는 요인으로 건조 조건(16-19), 건조 전 침지용 액 침지시간(7), 부재료 종류(11-15) 등 다양한 요인들이 영향을 미치는 것으로 보고되어 있다.

\section{닭 가슴살 육포의 수분활성도}

감미제의 사용은 육포 제조 시 단맛을 부여하는 목적 이외에도 수분과 결합하여 미생물이 이용할 수 없는 결합수 분 형태로 전환시키는 역할을 하기 때문에 제품의 수분을 유지하면서도 수분활성도를 낮출 수 있다. 감미제는 종류 에 따라 수분과 결합하는 특성이 다르기 때문에 사용된 감미제의 종류는 최종 제품의 수분활성도에 영향을 주게 된다. 본 연구에서 7종의 감미제를 사용하여 제조한 닭 가슴 살 육포의 수분활성도(Table 3)는 감미제의 종류에 따라 유의적으로 다르게 나타났으며 가장 낮은 수분활성도는 0.744 로 복분자 엑기스를 사용한 육포였으며 그 다음으로 꿀 0.755 , 황설탕 0.772 , 조청 0.777 , 프락토올리고당 0.783 , 파인애플 농축액 0.793 , 설탕 0.812 로 순으로 높아지는 것으 로 나타났다. Banwart(4)는 수분활성도 0.85 이상에서는 미 생물이 쉽게 성장한다고 보고하면서 저장기간을 위해서는 설탕이나 소금 등의 첨가로 수분활성도를 0.7 수준으로 낮 춰야 한다고 하였다. Jung 등(35)에 따르면 시중에 판매되는 우육포의 수분함량은 약 $20 \%$ 정도이며 이 때의 수분활성도 는 0.60-0.70으로 보고하였다. 본 연구에서 제조된 닭 가슴 살 육포는 수분활성도 $0.74-0.81$ 의 범위를 나타내어 설탕을

Table 4. Color of chicken breast jerky prepared using different types of sweeteners

\begin{tabular}{cccc}
\hline \multirow{2}{*}{ Sweeteners $^{1)}$} & \multicolumn{3}{c}{ Hunter color values } \\
\cline { 2 - 4 } & $\mathrm{L}$ & $\mathrm{a}$ & $\mathrm{b}$ \\
\hline WS & $31.21 \pm 0.05^{\mathrm{g} 2)}$ & $4.81 \pm 0.07^{\mathrm{e}}$ & $7.68 \pm 0.05^{\mathrm{e}}$ \\
BS & $34.84 \pm 0.07^{\mathrm{b}}$ & $5.66 \pm 0.04^{\text {cd }}$ & $9.74 \pm 0.02^{\mathrm{d}}$ \\
RS & $36.20 \pm 0.15^{\mathrm{a}}$ & $5.53 \pm 0.10^{\mathrm{d}}$ & $10.70 \pm 0.14^{\mathrm{a}}$ \\
FO & $34.42 \pm 0.02^{\mathrm{c}}$ & $6.60 \pm 0.04^{\mathrm{a}}$ & $10.58 \pm 0.03^{\mathrm{b}}$ \\
PC & $32.92 \pm 0.15^{\mathrm{d}}$ & $5.87 \pm 0.02^{\mathrm{b}}$ & $6.98 \pm 0.03^{\mathrm{f}}$ \\
RCE & $32.01 \pm 0.33^{\mathrm{f}}$ & $3.18 \pm 0.23^{\mathrm{f}}$ & $6.21 \pm 0.05^{\mathrm{g}}$ \\
H & $32.44 \pm 0.03^{\mathrm{e}}$ & $5.69 \pm 0.06^{\mathrm{c}}$ & $9.88 \pm 0.07^{\mathrm{c}}$ \\
\hline
\end{tabular}

\footnotetext{
${ }^{1)} \mathrm{WS}$, white sugar; BS, brown sugar; RS, rice syrup; FO, fructo-oligosaccharide; $\mathrm{PC}$, pineapple concentrate; RCE, Rubus coreanus extract; H, honey.

${ }^{2)}$ All values are mean $\pm \mathrm{SD}$. Values with different superscript small letters in the same column are significantly different by Duncan's multiple range test at $p<0.05$. $\mathrm{a}>\mathrm{b}>\mathrm{c}>\mathrm{d}>\mathrm{e}>\mathrm{f}>\mathrm{g}$.
}

제외한 감미제 처리군의 경우 $50^{\circ} \mathrm{C}$ 에서 9 시간 건조로 미생 물 성장이 억제되는 수준의 수분활성도를 얻을 수 있는 것으로 나타났으나 설탕을 첨가한 시료군의 경우 미생물학 적으로 안전한 0.8 이하의 수분활성도를 얻기 위해서는 건 조 시간을 더 연장하는 것이 필요할 것으로 보여진다.

\section{닭 가슴살 육포의 색도}

닭 가슴살 육포의 색도를 측정한 결과는 Table 4 와 같다. 육포의 색도는 L 값은 31.21-36.20, a값은 3.18-6.60, b값은 6.21-10.70 범위 안에서 사용된 감미제 종류에 따라서 유의 적인 차이를 나타내었으며 전체적으로 황색빛을 띠는 어두 운 붉은색을 나타내었다. 닭은 근섬유에 마이오글로빈 함 량이 적은 백색육으로 우육과 돈육 같은 적색육의 짙은 붉은색이 아닌 연한 핑크색을 띠고 있으나 침지하는 과정에 서 침지용액 재료로 사용된 간장에 의해 어둡게 착색이 되어 최종 건조된 닭 가슴살 육포의 색은 육안으로 볼 때 우 육포나 돈 육포와 유사한 색을 보이는 것을 확인할 수 있었다. 사용된 감미제의 특성에 따라 $\mathrm{L}, \mathrm{a}$, 그리고 $\mathrm{b}$ 값에서 는 유의적인 차이가 나타났으나 시각적으로는 두드러진 차이가 나타나지 않았다.

\section{닭 가슴살 육포의 조직감}

우육포나 돈육포의 경우 건조 후 질긴 조직감으로 인한 관능성 저하로 인하여 연육제를 처리하여 단단한 조직감을 개선하는 연구가 보고되어 있다( 35,36$)$. 본 연구에서는 예 비 실험으로 연육제를 처리하여 제조한 닭 가슴살 육포의 경우 원료육의 부드러운 조직감이 연육제의 처리로 인하여 씹히는 육포로서의 질감이 사라지고 부서지는 특성을 나타 내어(data not shown) 본 연구에서는 조직감을 부드럽 게 하기 위해 처리되는 연육제를 사용하지 않고 감미제와 관능 성 개선을 위한 부재료들로 닭 가슴살 침지용액을 이용하여 육포를 제조하였다. 총 7종의 감미제를 달리하여 제조한 닭 가슴살 육포의 조직감을 측정한 결과는 Table 5 와 같다. 경도(hardness)는 입안에서 이로 육포를 절단시 필요한 변 형되는 힘을 의미하며 검성(gumminess)은 육포를 혀나 치 아로 분해하는데 필요한 힘을 나타내는데 감미제에 종류를 달리하여 제조한 닭 가슴살 육포의 경도와 검성은 각각 9,775.3-10,222.7 g와 5,864.3-6,944.3 g의 범위 안에서 유의 적인 차이가 나타나지 않았다. 응집성(cohesiveness)은 식품 에 혀나 치아로 힘을 주었을 때 부서지지 않고 서로 결합하 려는 성질을 의미하는데 파인애플 농축액을 이용한 육포가 다른 감미제 첨가군에 비해 유의적으로는 높게 나타났으나 그 범위가 0.6-0.7로 매우 미미한 차이를 나타내었다 $(\mathrm{p}<0.05)$. 탄력성(springiness)은 육포에 혀나 치아로 힘을 주어 이 힘이 제거된 후에 변형된 육포가 변형되기 전의 상태로 돌아가는 속도를 뜻하며 측정 결과 설탕, 조청, 파인 애플 농축액>복분자 엑기스>프락토올리고당>황설탕 또는 꿀 등의 순으로 유의적으로 높게 나타나 $(\mathrm{p}<0.05)$ 감미제 
Table 5. Textural properties of chicken breast jerky prepared using different types of sweeteners

\begin{tabular}{cccccc}
\hline \multirow{2}{*}{ Sweeteners $^{1)}$} & \multicolumn{5}{c}{ Texture parameters } \\
\cline { 2 - 6 } & Hardness $(\mathrm{g})$ & Cohesiveness & Springiness $(\mathrm{mm})$ & Gumminess $(\mathrm{g})$ & Chewiness $(\mathrm{mJ})$ \\
\hline WS & $\left.9775.3 \pm 454.7^{\mathrm{ns} 2}\right)$ & $\left.0.7 \pm 0.1^{\mathrm{ab}}\right)$ & $1.8 \pm 0.2^{\mathrm{a}}$ & $6944.3 \pm 873.3^{\text {ns }}$ & $120.8 \pm 32.5^{\mathrm{ab}}$ \\
BS & $10210.0 \pm 319.1$ & $0.7 \pm 0.1^{\mathrm{ab}}$ & $1.0 \pm 0.3^{\mathrm{c}}$ & $6818.7 \pm 1070.4$ & $64.1 \pm 11.6^{\mathrm{d}}$ \\
RS & $10095.7 \pm 116.7$ & $0.6 \pm 0.1^{\mathrm{b}}$ & $1.9 \pm 0.3^{\mathrm{a}}$ & $5864.3 \pm 827.2$ & $108.8 \pm 6.0^{\mathrm{bc}}$ \\
FO & $9799.0 \pm 168.9$ & $0.7 \pm 0.1^{\mathrm{ab}}$ & $1.3 \pm 0.2^{\mathrm{bc}}$ & $6778.3 \pm 757.3$ & $85.4 \pm 1.9^{\text {cd }}$ \\
PC & $9780.3 \pm 147.2$ & $0.7 \pm 0.1^{\mathrm{a}}$ & $2.0 \pm 0.2^{\mathrm{a}}$ & $7202.3 \pm 754.7$ & $137.3 \pm 2.1^{\mathrm{a}}$ \\
RCE & $10222.7 \pm 130.3$ & $0.6 \pm 0.1^{\mathrm{ab}}$ & $1.7 \pm 0.2^{\mathrm{ab}}$ & $6534.3 \pm 691.0$ & $108.6 \pm 8.9^{\mathrm{bc}}$ \\
H & $10028.0 \pm 417.5$ & $0.7 \pm 0.1^{\mathrm{ab}}$ & $1.0 \pm 0.3^{\mathrm{c}}$ & $6935.0 \pm 1019.0$ & $65.1 \pm 12.4^{\mathrm{d}}$ \\
\hline
\end{tabular}

${ }^{1)}$ WS, white sugar; BS, brown sugar; RS, rice syrup; FO, fructo-oligosaccharide; PC, pineapple concentrate; RCE, Rubus coreanus extract; H, honey.

${ }^{2)} \mathrm{ns}$, not significant.

${ }^{3)}$ All values are mean \pm SD (five determinations). Values with different superscript letters in the same column are significantly different by Duncan's multiple range test at $p<0.05$ $\mathrm{a}>\mathrm{b}>\mathrm{c}>\mathrm{d}$.

Table 6. Sensory properties of chicken breast jerky prepared using different types of sweeteners

\begin{tabular}{cccccc}
\hline \multirow{2}{*}{ Sweeteners $^{\mathrm{1}}$} & \multicolumn{5}{c}{ Sensory parameters } \\
\cline { 2 - 6 } & Color & Flavor & Taste & Texture & Overall acceptability \\
\hline WS & $\left.2.80 \pm 0.77^{\mathrm{ns} 2}\right)$ & $2.67 \pm 1.29^{\mathrm{ns}}$ & $3.20 \pm 1.15^{\mathrm{b} 3)}$ & $3.33 \pm 0.62^{\mathrm{ns}}$ & $3.00 \pm 0.93^{\mathrm{b}}$ \\
BS & $3.73 \pm 0.59$ & $3.40 \pm 0.74$ & $2.87 \pm 0.92^{\mathrm{bc}}$ & $3.40 \pm 0.83$ & $3.07 \pm 0.80^{\mathrm{b}}$ \\
RS & $3.33 \pm 0.90$ & $3.00 \pm 1.00$ & $3.07 \pm 0.26^{\mathrm{b}}$ & $3.27 \pm 1.03$ & $3.13 \pm 0.92^{\mathrm{b}}$ \\
FO & $3.27 \pm 0.70$ & $2.87 \pm 0.74$ & $2.87 \pm 1.19^{\mathrm{bc}}$ & $2.93 \pm 1.33$ & $3.20 \pm 0.77^{\mathrm{b}}$ \\
PC & $3.33 \pm 0.90$ & $2.60 \pm 1.30$ & $2.13 \pm 1.13^{\mathrm{c}}$ & $3.60 \pm 0.74$ & $2.13 \pm 0.83^{\mathrm{c}}$ \\
RCE & $3.07 \pm 1.22$ & $3.33 \pm 0.98$ & $4.07 \pm 0.96^{\mathrm{a}}$ & $3.47 \pm 0.74$ & $4.00 \pm 0.85^{\mathrm{a}}$ \\
H & $3.27 \pm 0.96$ & $3.27 \pm 1.16$ & $3.53 \pm 1.13^{\mathrm{ab}}$ & $3.40 \pm 0.63$ & $3.53 \pm 0.83^{\mathrm{ab}}$ \\
\hline
\end{tabular}

${ }^{11}$ WS, white sugar; BS, brown sugar; RS, rice syrup; FO, fructo-oligosaccharide; PC, pineapple concentrate; RCE, Rubus coreanus extract; H, honey.

${ }^{2)} \mathrm{ns}$, not significant.

${ }^{3)}$ All values are mean \pm SD. Values with different superscript small letters in the same column are significantly different by Duncan's multiple range test at $p<0.05$. $a>b>c$.

종류에 따라 육포의 탄력성에 영향을 미치는 것을 확인할 수 있었다. 한편, 씹힘성(chewiness)은 육포가 삼켜지기 위 해 필요한 씹음 단계의 수를 의미하는데 육포 제조에 사용 된 감미제에 따라 유의적인 차이를 나타내어 파인애플 농축 액 시료군이 $137.3 \mathrm{~mJ}$ 로 가장 높게 나타났으며 황설탕과 꿀을 이용한 육포가 가장 낮은 값을 보였다( $<<0.05)$. 감미제 의 종류에 따라서 건조 특성이나 최종 중간수분식품의 보수 성에 영향을 미치게 되며 이는 조직감의 변화를 유도할 수 있다. 본 연구에서 제조된 닭 가슴살 육포의 경우 사용된 감미제에 종류에 따른 조직감의 유의적인 차이를 확인할 수 있었으며 이러한 경향이 특히 중간수분식품에서 느낄 수 있는 탄력성이나 검성에서 나타남을 확인할 수 있었다. 한편, Jung 등(34)은 육포의 조직감은 저장 중 경시적으로 수분활성도와 수분함량이 감소하면서 보다 거칠어지고 딱 딱한 조직감으로 변화되는 관능품위 손상에 대하여 언급하 였는데 이러한 육포의 변질을 최소화하기 위해서는 포장 방법 및 저장 중 조직감 및 수분활성도 변화 등에 관한 연구가 필요할 것으로 보인다.

\section{닭 가슴살 육포의 관능적 특성}

감미제를 달리하여 제조한 닭 가슴살 육포의 관능적 특 성을 색(color), 향(flavor), 맛(taste), 조직감(texture), 전체적 인 기호도(overall acceptability) 항목에 대하여 5 점 기호척 도법으로 평가한 결과는 Fig 2 와 같다. 닭 가슴살 육포의 색은 황설탕 첨가군이 3.73으로 유의적으로 가장 높은 점수 를 얻었으나 $(\mathrm{p}<0.05)$ 다른 시료군과의 기호도 차이는 적은 것으로 나타났다. 이는 모든 시료에서 간장을 기본 재료로 사용했으며 감미제에 의한 색도의 차이는 크지 않기 때문에 육안으로 구별되는 육포의 색도 차이는 크지 않은 것으로 보여진다. 닭 가슴살 육포의 맛에 대한 기호도 평가는 사용 된 감미제의 종류에 따라 유의적인 차이를 보였다. 복분자 엑기스 첨가군이 4.07 의 값으로 맛에서 가장 높은 기호도를 얻었으며 다음으로 꿀 3.53 , 백설탕 3.20 , 조청 3.07 , 황설탕 2.87 , 프락토올리고당 2.87 , 파인애플 농축액 2.13 의 순으로 기호도가 감소하는 것으로 나타났다 $(\mathrm{p}<0.05)$. 이에 반하여 향과 조직감은 감미제를 달리한 육포 시료들에서 유의적인 차이가 나타나지 않았다. 육포의 조직감 측정에서 경도에 
서는 차이가 없지만 탄력성과 검성에서는 차이를 보였으나 이러한 기기적인 조직감 측정에서 나타난 차이가 관능적 기호도에서 조직감 지표에는 영향을 미치지 못하는 미미한 수준의 차이인 것이라 생각된다. 육포의 전체적 기호도는 복분자 엑기스 첨가군이 4.00 으로 가장 높게 나타났으며 다음으로 꿀 3.53 , 프락토올리고당 3.20 , 조청 3.13 , 황설탕 3.07 , 백설탕 3.00 , 파인애플 2.31 의 순으로 나타나 $(\mathrm{p}<0.05)$ 육포의 전체적 기호도가 맛에 대한 기호도에 의존하는 경향 을 나타내는 것으로 보여진다. 관능검사 패널의 주관적인 의견에 따르면 육포의 단단하고 쫄깃한 조직감을 선호한다 는 패널과 부드러워 쉽게 씹을 수 있는 조직감을 선호하는 패널이 있는 것으로 조사되어 향후 소비자들의 연령과 조직 감에 대한 선호도에 따라 조직감을 수준별로 구분하여 제조 하는 방법을 고려해 보는 것도 필요할 것으로 보여진다.

\section{닭 가슴살 육포의 산화 안정성}

본 연구에서 제조된 7 종의 육포 중에서 약 $24.0 \%$ 의 수분 함량을 보유하면서도 수분활성도와 $\mathrm{pH}$ 가 가장 낮고 관능 성이 가장 우수하게 나타난 복분자 엑기스를 감미제로 이용 하여 제조한 닭 가슴살 육포의 저장 중 산화안정성을 조사 하였다. 저장온도 $50^{\circ} \mathrm{C}$ 에서 2 주 동안 변화되는 닭 가슴살 육포의 TBARS 변화를 측정한 결과는 Fig. 1 과 같다. 대조구 로는 이와 동일한 방법으로 돼지 뒷 다리살과 소 우둔살을 이용하여 제조한 육포를 사용하였다. 복분자 엑기스를 이 용한 닭 가슴살 육포의 경우 저장 기간 2주 동안 TBARS 초기값 $50.50 \mathrm{MDA} \mathrm{mg} / \mathrm{kg}$ 이 $58.30 \mathrm{MDA} \mathrm{mg} / \mathrm{kg}$ 으로 미미한 증가를 보여 지방 산패가 거의 진행되지 않았던 반면 돈 육포의 경우 TBARS가 저장 초기부터 빠르게 증가하여 2주 후에는 $98.03 \mathrm{mg} / \mathrm{kg}$ 으로 증가하였으며 우 육포의 경우도 돈육포에 비하여 TBARS 증가 속도는 낮았으나 저장기간 10 일 이후부터 급격한 증가를 보이기 시작하여 2주 저장

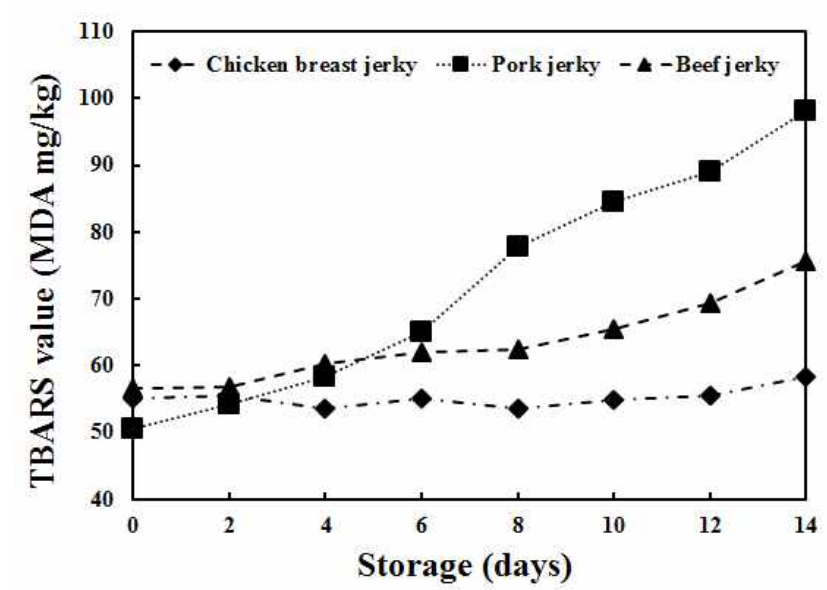

Fig. 1. Changes in thiobarbituric acid reactive substance (TBARS) values of chicken, pork, and beef jerky dried at $50^{\circ} \mathrm{C}$ for $9 \mathrm{~h}$ after marination in $R$. coreanus extract.
후에는 $75.60 \mathrm{MDA} \mathrm{mg} / \mathrm{kg}$ 값을 나타내어 지방 산패가 진행 되었음을 나타내었다. 관능적으로 돈 육포와 우 육포의 경 우 저장 4 일째부터 약한 산패취를 나타내었고 10 일 이후에 는 강한 산패취를 나타낸 반면 닭 가슴살 육포의 경우 저장2 주 동안 산패취는 거의 감지되지 않았다. 이러한 우육포에 서의 빠른 지방산패 현상은 다른 연구에서도 보고되었는데 $\mathrm{Kang}(38)$ 은 $18^{\circ} \mathrm{C}$ 에서 우육포를 저장 시 TBARS 초기값 $42.08 \mathrm{mg} / \mathrm{kg}$ 이 4주 이후 $187.20 \mathrm{mg} / \mathrm{kg}$ 으로 증가했다고 보고 하여 우육이나 돈육과 같이 지방 함량이 있는 육포의 경우 저장 시 산소와의 접촉을 차단하는 것이 필요함을 보여주었 다. 한편, $\mathrm{Cho}(7)$ 는 제조 시 사용하는 당과 건조방법에 따른 육포의 특성에 관한 연구에서 건조시간이 길어질수록 공기 와의 접촉시간 증가로 인하여 지질 산패가 가속화된다고 보고하여 건조조건과 방법도 육포의 산화안정성에 영향을 줄 수 있음을 나타내었다. 본 연구 결과와 같이 닭 가슴살 육포가 돈 육포나 우 육포에 비해 지방 산패가 느리게 진행 되는 것은 닭 가슴살의 지방 함량 $(<1 \%)$ 이 우 육포나 돈 육포(7-8\%)에 비하여 낮기 때문인 것이라 생각된다. 일반적 으로 육포의 지방 산패를 방지하기 위해서는 제조 시 건조 방법, 포장 방법, 개봉 이후 섭취기간 등에 있어서 산소와의 접촉을 최소화하는 것이 필요하나 닭 가슴살 육포의 경우 지방함량이 낮아 이러한 건조 과정이나 진공포장을 개봉한 이후 산소와의 접촉이 상당 기간 동안 지속되어도 지방 산패가 매우 미미하게 진행될 것이라 생각된다.

\section{요 약}

본 연구는 저지방 및 고단백 부위인 닭 가슴살을 백설탕, 황설탕, 조청, 프락토올리고당, 파인애플 농축액, 복분자 엑기스, 꿀 등 총 7종의 감미제를 사용한 침지용액에 각각 침지 처리 후 $50^{\circ} \mathrm{C}$ 에서 9 시간 건조하여 닭 가슴살 육포를 제조하고 이들의 이화학적 및 관능적 특성을 조사하였다. 또한, 품질 특성이 우수한 닭 가슴살 육포를 선정하여 $50^{\circ} \mathrm{C}$ 에서 저장하며 대조군(돈 육포 및 우 육포)과 지방산패 속도 를 비교하였다. 제조된 닭 가슴살 육포는 수분 22.5-25.0\%, 조단백 41.0-46.6\%, 조지방 0.4-1.0\%로 저지방 고단백 식품 임을 알 수 있었다. 닭 가슴살 육포 제조에 사용된 감미료의 종류는 육포의 $\mathrm{pH}$ 5.2-5.9, 총균수 $\left(2.5-6.2 \times 10^{4} \mathrm{CFU} / \mathrm{g}\right)$ 및 수분활성도(0.744-0.812) 수준에 유의적으로 영향을 미치 는 것으로 나타났다 $(\mathrm{p}<0.05)$. 수분활성도와 $\mathrm{pH}$ 는 복분자 엑기스를 사용한 닭 가슴살 육포에서 가장 낮았으며 백설탕 을 사용한 시료군에서 가장 높았다. 닭 가슴살 육포의 응집 성, 탄력성, 씹힘성은 사용한 감미제의 종류에 따라 유의적 인 차이를 보였으나 $(\mathrm{p}<0.05)$ 경도와 검성에서는 유의적인 차이가 관찰되지 않았다. 한편, 관능평가 결과에서는 복분 자 엑기스 시료군이 맛과 전체적인 기호도에서 가장 높게 
평가되었다. 복분자 엑기스를 사용한 닭 가슴살 육포와 이 와 동일한 방법으로 제조한 돈 육포와 우 육포를 대조군으 로 하여 $50^{\circ} \mathrm{C}$ 에서 저장 시 돈 육포의 TBARS가 가장 빠르게 증가하여 저장 2주 후 $98.03 \mathrm{MDA} \mathrm{mg} / \mathrm{kg}$, 우 육포의 경우 $75.60 \mathrm{MDA} \mathrm{mg} / \mathrm{kg}$ 를 나타낸 반면, 복분자 엑기스 닭 가슴살 육포의 경우는 이보다 훨씬 낮은 $58.30 \mathrm{MDA} \mathrm{mg} / \mathrm{kg}$ 값을 나타내어 지방산패가 우 육포와 돈 육포에 비해 상당히 느리게 진행됨을 알 수 있었다. 본 연구 결과로 닭 가슴살은 돈육과 우육에 비하여 산화안정성이 우수한 저지방-고단백 육포 제조에 바람직한 원료가 될 수 있음을 확인할 수 있었 으며, 닭 가슴살 육포 제조 시 복분자 엑기스 침지용액을 사용함으로 낮은 수분활성도와 우수한 관능성을 가진 제품 을 제조할 수 있을 것으로 사료된다.

\section{감사의 글}

이 논문은 2016년 순천대학교 지원에 의하여 수행된 것 으로 이에 감사를 드립니다.

\section{References}

1. Statistics Korea (2015) Korea Livestock Survey Repor of KOSIS. KOSIS 1-1240000-000479-08

2. Yang IY, Im PR, Kang JS, Kwak HS, Jeong YH, Kim MS, Lee YS (2015) Quality of commercial broiler breast meat retailed in Korea. J Korean Soc Food Sci Nutr, 44, 1693-1699

3. Faith NG, Le Countour NS, Alvarenga MB, Calicioglu M, Buege DR, Luchansky JB (1998) Viability of Escherichia coli $\mathrm{O} 157: \mathrm{H7}$ in ground and formed beef jerky prepared at levels of 5 and $20 \%$ fat and dried at $52,57,63$, or $68^{\circ} \mathrm{C}$ in a home-style dehydrator. Int $\mathrm{J}$ Food Microbiol, 41, 213-221

4. Gailani MB, Fung DY (1986) Critical review of water activities and microbiology of drying of meats. Crit Rev Food Sci Nutr, 25, 159-183

5. Torres EAFS, Shimokomaki M, Franco BDGM, Landgraf M (1994) Parameter determining the quality of charqui, an intermediate moisture meat product. Meat Sci, 38, 229-234

6. Song HH (1997) The effects of glycerol, rice syrup and honey on the quality and storage characteristics of beef jerky. MS Thesis, Konkuk University, Korea, p 10-24

7. Cho EJ, Lee JE (2000) The effect of addition of kinds of sugar and drying method on quality and storage characteristics of beef jerky. Korean J Food cook Sci, $16,511-520$

8. Park GS, Lee SJ, Jeong ES (2002) The quality characteristics of beef jerky according to the kinds of saccharides and the concentrations of green tea powder. J Korean Soc Food Sci Nutr, 31, 230-235

9. Lee SW, Lee BS, Cha WS, Park JH, Oh SL, Cho YJ, Kim JK, Hong JH, Lee WY (2004) Diffusion of salt and drying characteristics of beef jerky. Korean J Food Preserv, 11, 508-515

10. Lim HJ, Jung EY, Kim GD, Joo ST, Yang HS (2012) Textural and sensory properties of beef jerky replaced salt with soybean paste, soy sauce or red pepper paste. J Agric Life Sci, 46, 97-104

11. Lee SJ, Park GS (2004) The quality characteristics of beef jerky prepared with various spices. Korean J Food Cookery Sci, 20, 489-497

12. Choi JH, Jung JY, Choi YS, Han DJ, Kin HY, Lee MA, Lee ES, Paik HD, Kim CJ (2006) The effects of marination condition on quality characteristics of cured pork meat and sensory properties of pork jerky. Korean J Food Sci An, 26, 229-235

13. Oh JS, Park JN, Kim JH, Lee JW, Byun MW, Chun SS (2007) Quality characteristics of pork jerky added with Capsicum annuum L. and Prunus mume Sieb. et Zucc. extract. J Korean Soc Food Sci Nutr, 36, 81-86

14. Han DJ, Jeong JY, Choi JH, Choi YS, Kim HY, Lee MA, Lee ES, Paik HD, Kim CJ (2008) Effects of various humectants on quality properties of pork jerky. Korean J Food Sci An, 28, 486-492

15. Kim HS, Seong PN, Kim MH (2012) Effect of cochineal color, green tea extract and grapefruit seed extract additions on pork jerky quality. Food Eng Prog, 16, 219-225

16. Han DJ, Jeong JY, Choi JH, Choi YS, Kim HY, Laa MA, Lee ES, Paik HD, Kim CJ (2007) Effects of drying conditions on quality properties of pork jerky. Korean J Food Sci An, 27, 29-34

17. Park CJ, Park CS (2007) The effects of drying method and spice extracts added to beef jerky on the quality characteristics of beef jerky. Korean J Food Cookery Sci, 23, 800-809

18. Park CJ, Kim ML, Park CS (2009) Effects of drying method and medicinal herb extract addition on the microstructure of beef jerky. Korean J Food Preserv, 16, 875-883

19. Nam KC, Jo CR, Lee KH (2012) Comparison of free 
amino acids and dipeptide contents, Warner-Bratzler shear force and aensory property of beef jerky manufactured with different drying methods. Korean $\mathbf{J}$ Food Sci An, 32, 796-802

20. Calicioglu M, Sofos JN, Samelis J, Kendall PA, Smith GC (2002) Destruction of acid and non-adapted Listeria monocytogenes during drying and storage of beef jerky. Food Microbiol, 19, 545-559

21. Konieczny P, Stangierski J, Kijowski J (2007) Physical and chemical characteristics and acceptability of home style beef jerky. Meat Sci, 76, 253-257

22. Banout J, Kucerova I, Marek S (2012) Using a double-pass solar drier for jerky drying. Energy Procedia, 30, 738-744

23. Albright SN, Kendall PA, Avens JS, Sofos JN (2003) Pretreatment effect on inactivation of Escherichia coli O157:H7 inoculated beef jerky. LWT-Food Sci Technol, 36, 381-389

24. Calicioglu M, Sofos JN, Samelis J, Kendall PA, Smith GC (2003) Effect of acid adaptation on inactivation of Salmonella during drying and storage of beef jerky treated with marinades. Int J Food Microbiol, 89, 51-65

25. Yoon Y, Calicioglu M, Kendall PA, Smith GC, Sofos JN (2005) Influence of inoculum level and acidic marination on inactivation of Escherichia coli O157:H7 during drying and storage of beef jerky. Food Microbiol, 22, 423-431

26. Yang CY (2006) Physicochemical properties of chicken jerky with pear, pineapple and kiwi extracts. Culi Sci Hos Res, 12, 237-250

27. Porto-Fett ACS, Call JE, Hwang CA, Juneja V, Ingham S, Ingham B, Luchansky JB (2009) Validation of commercial processes for inactivation of Escherichia coli O157:H7, Salmonella Typhimurium, and Listeria monocytogenes on the surface of whole-muscle turkey jerky. Poult Sci, 88, 1275-1281
28. AOAC (1995) Official Methods of Analysis. $15^{\text {th }}$ ed, Association of Official Analytical Chemists, Washington DC, USA, p 210-219

29. Park GS, Lee SJ, Jeong ES (2002) The quality characteristics of beef jerky according to the kinds of saccharides and the concentrations of green tea powder. J Korean Soc Food Sci Nutr, 31, 230-235

30. Kim YH (1998) A report of the food standardization (KS) of agricultural and livestock products. Korea Food Research Institute, p 774-803

31. USDA database (2008) Poultry products.https://ndb.nal.usda.gov (accessed on April 2013)

32. Yang CH, Lee SH (2002) A evaluation of quality of the marketing jerky in domestic: I. Investigating of outward appearance, food additives, nutrient content and sanitary state. Korean J Food Nutr, 15, 197-202

33. Lee JA, Kim HY (2016) Development of restructured chicken thigh jerky added with red pepper seed powder. J Korean Soc Food Sci Nutr, 45, 1333-1337

34. Barbut S (1988) Microstructure of reduced salt meat batters as affected by polyphosphates and chopping time. J Food Sci, 53, 1300-1304

35. Jeong SW, Kim YS, Kim YH, Paik YS (1994) Quality changes of beef jerky during storage. J Anim Sci Technol, 36, 693-697

36. Choi YI, An YS, Hong SK (1993) Effect of emulsion addition on binding ability and storage characteristics of restructured pork jerky. J Anim Sci Technol, 35, 223-229

37. Choi YI, An GY (1996) Effects of phosphate type and addition level on binding ability, microstructure and storage characteristics of restructured pork jerky. J Anim Sci Technol, 38, 159-179

38. Kang HJ (2011) A study on the quality characteristics of beef jerky added with Perilla frutescens var. acuta. MS Thesis, Sejong, University, Korea, p 31-32 